\title{
CZŁOWIEK W KOSMOSIE. BARIERY ADAPTACYJNE Z PERSPEKTYWY ASTRONAUTYCZNEJ
}

\begin{abstract}
Streszczenie. Praca ma charakter poglądowy i dotyczy postępów współczesnej astronautyki ze szczególnym uwzględnieniem barier medycznych i psychologicznych uniemożliwiających długoterminowe przebywanie człowieka Kosmosie. Związki intelektualne i emocjonalne człowieka z Kosmosem są znane od zarania dziejów o czym świadczy, z jednej strony, rozwój kosmologii i astronomii, a z drugiej - ikonografia religijna i literatura piękna oraz proza fantastyczno-naukowa. Zebrane dane naukowe i mity na temat Kosmosu są podstawą budowania narzędzi (np. teleskopów, satelit, sond kosmicznych) do ich weryfikacji. Jednakże dopiero w XX wieku człowiek postanowił osobiście, krok po kroku, nie tylko intelektualnie ale „zmysłowo dotknąć” Kosmosu. Kroki te to rozwój narzędzi transportu pozaziemskiego, takich m.in. jak: statki kosmiczne (orbitalne i międzyplanetarne) oraz stacje kosmiczne. Działalność ta nazwana w literaturze przedmiotu astronautyką, wzbudziła nowe nadzieje na eksploracje Kosmosu, ale także nowe mity.
\end{abstract}

Słowa kluczowe: kosmos, astronautyka, medycyna i psychologia kosmiczna

1. Wstęp. 2. Racjonalne przesłanki psychologii kosmicznej. 2.1. Problemy medycyny i psychologii hipergrawitacyjnej. 2.2. Problemy medycyny i psychologii hipograwitacyjnej. 3. Nowożytna „Arka Noego”, czyli bariery astronautyki międzyplanetarnej. 4. Refleksja zamiast zakończenia.

\section{WSTĘP}

W Księdze Rodzaju czytamy między innymi: „...na początku Bóg stworzył niebo i ziemię" ( $\operatorname{Rdz} 1,1)$, dlatego też człowiek od zarania dziejów, obserwując gwiaździste nocne niebo, był zafascynowany Kosmosem, co przejawiało się, z jednej strony, legendami i wierzeniami, a z drugiej - pseudonaukowymi i naukowymi teoriami. Powszechną świadomość niedostępności Kosmosu tłumaczy się niekiedy twierdzeniami, że jest on siedzibą Bogów (niebo), do których nie ma dostępu cielesny człowiek i jego „grzeszna” dusza. Człowiek 
intuicyjnie wyczuwa, że jest częścią Kosmosu, który ma określony wpływ na jego życie, o czym świadczą m.in. gwiezdne horoskopy, zakładające deterministyczny wpływ kosmosu na losy pojedynczego człowieka. $\mathrm{W}$ różnym czasie, w zależności od stopnia rozwoju nauki w ogóle (np. astronomii, fizyki), a nauk o człowieku w szczególności (antropologii filozoficznej, medycyny, psychologii), różne były próby dookreślenia tego wpływu na losy człowieka. Lęk i strach z jednej strony oraz podziw i fascynacje tajemniczymi siłami przyrody $z$ drugiej, uzasadniają wciąż przypisywanie ciałom niebieskim wpływu nie tylko na zjawiska przyrodnicze (urodzaje, burze, choroby, erupcje wulkanów, itp.), ale także na szczęście i cierpienie ludzi.

\section{RACJONALNE PRZESŁANKI PSYCHOLOGII KOSMICZNEJ}

Grawitacja definiowana jest najprościej jako powszechna siła przyciągania, działająca pomiędzy ciałami mającymi masę. Szczególnie przydatna dla naszych celów jest II Zasada Dynamiki Newtona, która twierdzi, że w inercjalnym układzie odniesienia jeśli siły działające na ciało nie równoważą się (czyli wypadkowa sił jest różna od zera), to ciało porusza się z przyspieszeniem wprost proporcjonalnym do siły wypadkowej, a odwrotnie proporcjonalnym do masy ciała. Dzięki temu można było obliczyć wartość przyspieszenia ziemskiego wynoszącą $g=9,81 \mathrm{~m} / \mathrm{s}^{2} .{ }^{1}$ Przeciwieństwem przyciągania ziemskiego jest nieważkość, którą odczuwa astronauta po wyjściu rakiety z gęstej atmosfery (powyżej ok. $90 \mathrm{~km}$ ) i wyłączeniu silników rakietowych jako tzw. chorobę kosmiczną, charakteryzującą się takimi objawami jak np. mdłości, wywołane przez zaburzenia pracy błędnika w warunkach braku ciążenia lub pogorszona sprawność koordynacji ruchowej, spowodowana zmianą tonusu mięśniowego. Towarzyszy

1 Wartość ta została przyjęta przez 3 Generalną Konferencję Miar i Wag w 1901 roku, jako odpowiadająca ziemskiemu przyspieszeniu grawitacyjnemu na poziomie morza na szerokości geograficznej około $45,5^{\circ}$. 
temu nie tylko dyskomfort, ale także nieadekwatne działania na poziomie sprawności psychomotorycznej. Mechanizmami wyjaśniającymi trudności funkcjonowania w sytuacji zwiększonej grawitacji $\mathrm{w}$ pojazdach $\mathrm{z}$ silnikiem odrzutowym oraz zredukowanej prawie do zera grawitacji ${ }^{2}$ (nieważkości) zajmują się dwa działy medycyny i psychologii grawitacyjnej: hipergrawitacyjna (przyspieszenia) i hipograwitacyjna (nieważkości).

\subsection{PROBLEMY MEDYCYNY I PSYCHOLOGII HIPERGRAWITACYJNEJ}

Skutki fizyczne przyspieszenia jako przyrostu prędkości w jednostce czasu wiążą się przede wszystkim ze zwielokrotnieniem ciężaru ciała, który zgodnie z II zasadą dynamiki Newtona, można obliczyć wg wzoru: $\mathrm{a}=\mathrm{F} / \mathrm{m}$. Tak np. $\mathrm{w}$ locie krzywoliniowym pilot ważący $80 \mathrm{~kg}$ przy przyspieszeniu dośrodkowym $50 \mathrm{~m} / \mathrm{s}^{2}\left(\mathrm{tj} .5 \times 9,81 \mathrm{~m} / \mathrm{s}^{2}\right)$ będzie poddany działającej na niego sile dośrodkowej o wartości $400 \mathrm{~kg}$.

Medycznym odpowiednikiem przyspieszenia jest „przeciążenie”, które określa wpływ sił mechanicznych działających na ustrój człowieka, związanych $\mathrm{z}$ bezwładnością ciała. Jest to stan określający rzeczywisty ciężar ciała pilota samolotu odrzutowego adekwatny do wielokrotności działania przyspieszenia, co ma swoje konsekwencje fizjologiczne - związane $z$ redestrybucją krwi oraz psychologicznezwiązane z pogorszeniem się koordynacji wzrokowo-motorycznej ${ }^{3}$.

2 Wbrew rozpowszechnionym opiniom nieważkość nie jest stanem, w którym na ciało nie oddziałują siły grawitacji. Np. w stacji kosmicznej mamy do czynienia ze stanem nieważkości, chociaż siły grawitacyjnego przyciągania przez Ziemię są tam tylko około 10\% mniejsze niż przy jej powierzchni. Stacja leci po orbicie okołoziemskiej dzięki temu, że grawitacja pełni w stosunku do niej funkcję siły dośrodkowej, nadającej stacji przyspieszenie dośrodkowe powodujące zakrzywienie jej toru lotu.

3 W medycynie lotniczej przyjęto podział przyspieszeń, którego podstawą jest kierunek przemieszczania krwi w wyniku jego działania i w odróżnieniu od przyspieszenia ziemskiego (g) oznaczone jest dużą literą G; por. Medycyna lotnicza i kosmiczna, red. S. Barański, Warszawa 1977. 


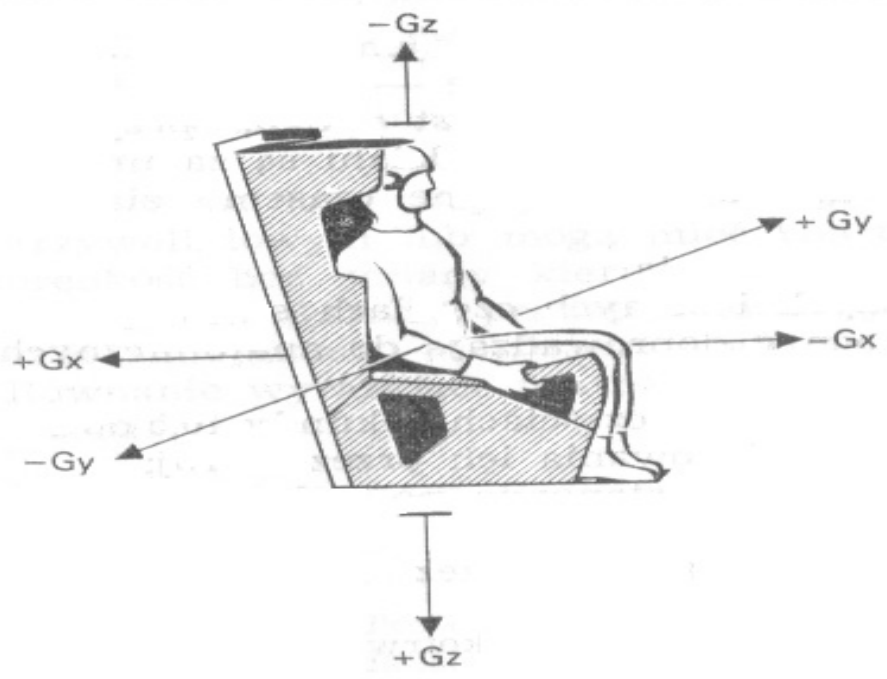

Rys. 1. Kierunki działania przyspieszeń na organizm pilota (w osi strzałkowej: od mostka do pleców +Gx, od pleców do mostka -Gx; w osi podłużnej ciała: od głowy do stóp +Gz, od stóp do głowy -Gz; w osi poprzecznej: z prawej strony na lewą +Gy i z lewej na prawą -Gy)

Najniebezpieczniejsze z punktu widzenia medycyny lotniczej jest przeciążenie $+\mathrm{Gz}$, czyli działające w osi podłużnej ciała $\mathrm{z}$ wektorem siły zwróconym w kierunku nogi-głowa, gdyż powoduje: (1) przemieszczenie krwi w kierunku przeciwnym, tj. w stronę dolnej połowy ciała; (2) spadek ciśnienia w górnych obszarach ciała; (3) przekrwienie i zastój w okolicach bioder i kończyn dolnych. Konsekwencje fizjologiczne przeciążenia $+\mathrm{Gz}$ dotyczą zaburzenia redestrybucji krwi, polegającego w pierwszym rzędzie na niedotlenieniu mózgu, co prowadzi do utraty przytomności, której prekursorami są takie objawy jak: poszarzenie obwodowego pola widzenia (grayout), całkowite zaciemnienie pola widzenia (blackout), co prowadzi w konsekwencji do tzw. widzenia tunelowatego (tunel vision) a w dalszej kolejności do utraty życia. Zwłaszcza jest to niebezpieczne w sytuacji tzw. 
przeciążeń udarowych znacznie przyspieszających wyżej opisane objawy, znane w literaturze przedmiotu jako G-LOC Phenomenon $(+G z-$ Induced Loss of Consciousness) poprzedzający utratę przytomności pilota.

Psychologiczne konsekwencje przeciążeń lotniczych prowadzą do trudności utrzymania dotychczasowej sprawności psychomotorycznej, związanej z ciężarem poszczególnych kończyn, odpowiedzialnych za precyzję wykonania ruchów dowolnych, co ilustruje ryc. 2.

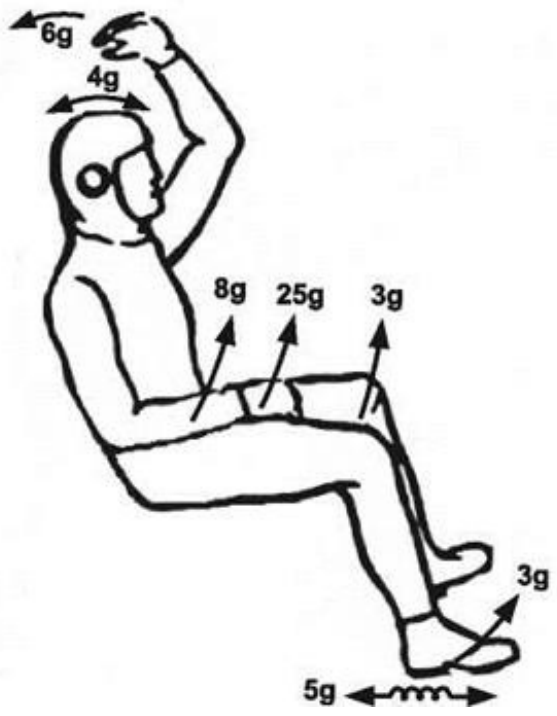

Rys.2. Różne wartości hipergrawitacji „g" ograniczające wykonywanie ruchów dowolnych

Kolejne skutki psychologiczne dotyczą zaburzenia orientacji przestrzennej. Powstają one przy zmianie prędkości w ruchu prostolinijnym. Powstaje wtedy wypadkowa siła złożona $z$ siły bezwładności i siły grawitacji błędnie identyfikowana przez mózg jako siła przyciągania ziemskiego. Jest ona przyczyną wielu złudzeń tzw. 
oczno-grawitacyjnych, jak np. złudzenia wznoszenia samolotu podczas przyspieszania i opadania podczas hamowania.

Mechanizm iluzji somato-grawitacyjnych polega na tym, że o położeniu ciała człowieka w przestrzeni informuje nas wiele układów biologicznych człowieka, takich jak: aparat przedsionkowy, układ wzrokowy, móżdżek, ośrodki czucia głębokiego, kora mózgowa, układ siatkowaty pnia mózgu i ich połączenia. Niezgodność sygnałów płynących z tych układów lub wyłączenie jednego z nich (np. kontroli wzrokowej) decyduje o pojawieniu się dezorientacji przestrzennej.

Przedstawione wybrane aspekty medyczne i psychologiczne oddziaływania hipergrawitacji na organizm człowieka stanowią ważne wstępne utrudnienia związane $z$ pokonaniem barier przyciągania ziemskiego $\mathrm{w}$ drodze do kosmosu oraz $\mathrm{w}$ trakcie powrotu $\mathrm{z}$ kosmosu na Ziemię.

\subsection{PROBLEMY MEDYCYNY I PSYCHOLOGII HIPOGRAWITACYJNEJ}

Na wstępie należy zaznaczyć, że doświadczenia z nieważkością są dla gatunku ludzkiego najnowsze w całym rozwoju filogenetycznym, gdyż wiążą się z możliwością pokonania bariery przyciągania ziemskiego. Wprawdzie przy zachowaniu pewnych warunków fizycznych (prędkości i kąta wznoszenia) możliwe jest krótkotrwałe (kilkadziesiąt sekund) wywołanie zjawiska nieważkości wewnątrz samolotu wykonującego lot paraboliczny po krzywej Keplera, to jednakże problemy medyczne i psychologiczne pojawiają się w sytuacji adaptacji do względnie długotrwałej pracy w warunkach nieważkości w lotach kosmicznych ${ }^{4}$. Opisane fragmenty wyników badań eksperymentalnych dotyczą symptomu tzw. ostrego okresu adaptacji do nieważkości, który wraz z indywidualnym doświadczeniem kosmonautów znika. Charakterystyczne dla tego krótkotrwałego stresu nieważkości jest zjawisko „dysocjacji emocji”, polegające na tym, że podczas gdy

4 K. Kwarecki, J.F. Terelak, Medycyna i psychologia kosmiczna, Warszawa 1980. 
niektóre reakcje motoryczne zdają się świadczyć o przeżywaniu strachu i zagrożenia (ruchy chwytne i reakcje poszukiwania podpory), inne równoległe reakcje wskazują na radość i euforię (śmiech). Wraz z nabywaniem doświadczenia ze stanem nieważkości występuje raczej zjawisko negacji emocji, polegające na tym, że w warunkach nastawienia na zadanie ten sam czynnik emocjonalny, skoncentrowany pierwotnie na przeżyciach własnych (dysocjacja emocji), działa mobilizująco na procesy poznawczo-wolicjonalne związane z pracą operatorską kosmonauty. Opisane zróżnicowanie reakcji emocjonalnych i motorycznych (aktywne v. bierne) w sytuacji nieważkości przejawiało się także w różnych wskaźnikach efektywności pracy operatorskiej. Tak np. u znacznej części badanych osób w warunkach nieważkości wydłuża się czas przetwarzania sygnałów cyfrowych, pogarsza się koordynacja wzrokowo-ruchowa, spowodowana niewystarczającym zrównoważeniem wysiłku mięśni antagonistycznych w nieważkości, szczególnie ruchów poziomych lub pętelkowych (ruchów szybkich i rytmicznych). Zaobserwowano także zjawisko osłabienia poczucia lokalizacji ręki podczas wykonywania testu „pisania”. Szczególnie znaczne błędy lokalizacji występują w wychyleniach ręki w górę lub w dół. Błędy lokalizacji zaobserwowano także w obrębie układu wzrokowego. Tak np. w pierwotnym zetknięciu się z nieważkością człowiek nie dostrzega wieloznaczności figur (np. rysunku waga v. profile głowy), co znika po okresie adaptacji. Medyczne skutki długoterminowej nieważkości u kosmonautów ${ }^{5}$ spowodowane są takimi czynnikami jak: brak rejestracji bodźców przez odpowiednie receptory grawitacji zlokalizowane w uchu wewnętrznym, brak obciążeń statycznych i dynamicznych układu mięśniowo-szkieletowego, eliminacja ciśnienia hydrostatycznego krwi i płynów tkankowych.

5 W literaturze przedmiotu można spotkać dwa określenia człowieka przebywającego w kosmosie: kosmonauta (ZSRR/Rosja) v. astronauta (USA). Różnica ta ma wyłącznie charakter polityczny. Por. P. Suedfeld, J. Brcic, K. Legkaia, Coping with the problems of space flight: Reports from astronauts and cosmonauts, Acta Astronautica 65(2009), 312-324. 
Ponieważ stan nieważkości $(0 \mathrm{~g})$ nie jest doświadczany w normalnych warunkach przyciągania ziemskiego (1g), stąd człowiek nie posiada wrodzonych mechanizmów adaptacyjnych.

Poza stanem nieważkości, który w okresie adaptacji jest przyczyną zakłócenia położenia w przestrzeni, obniżenia zdolności do pracy, ograniczenia aktywności ruchowej (hipokinezja), dyskomfortu, itp., wymienia się inne źródła stresu, jak np.: mała powierzchnia życiowa, specyfika odżywiania (brak świeżych i naturalnych produktów), woda odzyskiwana z produktów przemiany materii, brak wyraźnego cyklu dobowego (16 razy dzień i noc), specyficzny mikroklimat (brak wymiany powietrza), konieczność pracy w tym samym zespole, ograniczenie możliwości wypoczynku i relaksu, brak intymności, przeciążenia pracą, konieczność stałego czuwania (wachty), przenikanie do wnętrza statku kosmicznego zabójczego dla życia promieniowania kosmicznego ${ }^{6}$, zagrożenie ze strony drobnych meteorytów w przypadku przebywania poza statkiem kosmicznym w celu napraw jego powierzchni zewnętrznych, itp. Czynniki te były przedmiotem badań własnych na stacji kosmicznej „Salut - 6”, prowadzonych w ramach międzynarodowego programu „Interkosmos - PAN - WIML” pod kryptonimem „Oprosnik” i „Relaks”.

Od czasu powstania idei wysłania w przestrzeń kosmiczną człowieka jako podstawowy, obok zdrowia kosmonauty, pojawił się problem sprawności psychicznej przyszłego kosmonauty. Medycyna kosmiczna, w obrębie której funkcjonuje psychologia kosmiczna, model wyjściowy zaczerpnęła z medycyny lotniczej, gdyż pierwsi kosmonauci mieli za podstawowe zadanie pilotowanie statków kosmicznych,

6 J.F. Terelak, Trends in Poland in Space Psychology Research, Aviation, Space and Environmental Medicine 609(1989)4, 352-360; M. Hermaszewski, Psychological aspects of space fligts, Polish Journal of Aviation Medicine and Psychology 19(2013)3, 5-8.

7 O.P. Kozerenko, G. Radkowski, J. Terelak, O. Mikshik, The problem of man's psychic adaptation under the space-flight conditions, w: Current Trends in Cosmic Biology and Medicine, II, red. K. Boda, V.M. Baranov, Slovak Academy of Sciences, Ivanka Pri Dunaji (CSRF) 1991, 91-94. 
do czego najlepiej się nadawali wyselekcjonowani wcześniej profesjonalni piloci wojskowi, cieszący się przede wszystkim dobrym zdrowiem, inteligencją i odpornością na stres ${ }^{8}$. Dwa główne ośrodki badania kandydatów do lotów kosmicznych, których doświadczenia wykorzystano w tworzeniu podwalin polskiej medycyny i psychologii kosmicznej, znajdowały się wówczas w USA i ZSRR9 .

Opierając się na wynikach badań eksperymentalnych oraz dotychczasowych doświadczeniach z lotów orbitalnych, należy zwrócić uwagę na fakt, że analizy psychologicznej zachowania się człowieka w statku kosmicznym czy stacji kosmicznej nie można odnosić tylko do braku grawitacji. Dotyczy to zwłaszcza lotów międzyplanetarnych $^{10}$, w których podstawowym problemem, obok przetrwania gatunku ludzkiego w stanie nieważkości, są nieznane jeszcze do końca efekty długotrwałej izolacji kulturowej i socjalnej (np. osamotnienie) ${ }^{11}$.

8 R.K. Ambler, J.R. Berkshire, W.F. O'Connor, The identification of potential astronauts, Naval School of Aviation Medicine, Pensacola 1961, Report 33; J.M. Christensen, J.M. Talbot, A review of the psychological aspects of space flight, Aviation, Space and Environmental Medicine 57(1986)3, 203-212.

9 Badania naukowe w latach osiemdziesiątych prowadzone były w obrębie dwóch organizacji międzynarodowych: NATO i Interkosmos. Polska psychologia kosmiczna powstała na bazie psychologii lotniczej w związku z lotem w Kosmos w roku 1978 pierwszego Polaka, mjra Mirosława Hermaszewskiego. Por. J.F. Terelak, Current research and trends in Aviation Psychology in Poland. Aviation, Space and Environmental Medicine 62(1991)9, 903-908; J.F. Terelak, The emergence and development of space psychology in Poland: The significance of historical space flight of Mirosław Hermaszewski, Polish Journal of Aviation Medicine and Psychology 19(2013)3, 23-36.

10 J.F. Terelak, Psychologiczne problemy długotrwałych lotów kosmicznych, Przegląd WL i WOPK (1979)10, 55-58; J.W. Eberhard, K.T. Smith, The problem of off duty time in long duration space mission: An annotated bibliography, McLean, Wirginia 1967, III; N. Kanas, From Earth's orbit to the outer planets and beyond: Psychological issues in space, Acta Astronautica (2011)68, 576-581.

11 A. Chaikin, The loneliness the long-distance astronaut, Discover (1985)2, 20-31. 


\section{NOWOŻYTNA „ARKA NOEGO”, CZYLI BARIERY ASTRONAUTYKI MIĘDZYPLANETARNEJ}

Współczesne badania kosmiczne mają charakter międzynarodowy i skoncentrowane są na budowie orbitującej wokół Ziemi stacji kosmicznej, która jest z jednej strony laboratorium naukowo-przemysłowym, a z drugiej - etapem pośrednim w locie na Marsa lub inne planety. Obecnie funkcjonuje na orbicie okołoziemskiej Międzynarodowa Stacja Kosmiczna (ISS - ang. International Space Station), ważąca 500 ton; posiada 16 modułów wymiennych (łącza standardowe), umożliwiających cumowanie statków kosmicznych (laboratoriów) i miejsca mieszkalne dla 6 kosmonautów ${ }^{12}$. Przewiduje się w przyszłości bazę hotelowa dla astronautów (badaczy i turystów) oraz wirówkę przeciążeniowa (centryfuga), która zmniejszy efekty wpływu nieważkości na organizm człowieka. Nim to jednak nastąpi, należy się liczyć z rzeczywistymi barierami, utrudniającymi, a nawet uniemożliwiającymi długotrwałe przebywanie w kosmosie ${ }^{13}$.

Pierwsza bariera kosmiczna dotyczy występowania całkowitej próżni, co uniemożliwia rozchodzenie się w niej fal dźwiękowych i utrudnia wymianę cieplną. Przyczyną śmierci organizmu wystawionego na działanie próżni kosmicznej jest brak tlenu, a co za tym idzie ustanie akcji serca po 90 sekundach i utrata przytomności oraz wstrzymanie oddechu, rozerwania płuc i dostanie się pęcherzyków gazu do opłucnej. Występuje również gwałtowne pocenie. Woda na powierzchni jamy ustnej i spoconych częściach ciała zagotuje się.

12 A.Y. Kalery, I.V. Sorokin, M.V. Tyurin, Human space exploration beyond the international space station: Role of relations of human, machine and the "Earth", Acta Astronautica (2010)67, 925-933; J.E. Boyda, N. Kanasa, V.I. Gushin, S. Saylor, Cultural differences in patterns of mood states on board the International Space Station, Acta Astronautica (2007)61, 668-671.

13 Przestrzeń kosmiczna to przestrzeń poza obszarem ziemskiej atmosfery. Ściśle wytyczonej granicy między przestrzenią powietrzną a przestrzenią kosmiczną nie ma. Fizycy przyjmują 80-100 km. 
Drugą barierą kosmiczną jest przenikanie ze wszystkich stron promieniowania kosmicznego, w tym niebezpiecznego dla życia promieniowania jonizującego (rentgenowskiego i gamma) oraz wysokoenergetycznych naładowanych cząsteczek. Do wnętrza kapsuły statku kosmicznego przenika codziennie 1,84 miliSievertów $(\mathrm{mSv})$ promieniowania. Dla porównania przeciętna roczna dawka promieniowania pochodzącego z naturalnych źródeł dla mieszkańca Europy to $2,7 \mathrm{mSv}$. Tymczasem 6 miesięcy spędzonych na stacji orbitalnej równoznaczne jest z pochłonięciem ok. $100 \mathrm{mSv}$, a 6 miesięcy w przestrzeni międzyplanetarnej-320 $\mathrm{mSv}^{14}$. Promieniowanie kosmiczne jest śmiertelną przeszkodą np. w locie na Marsa. Astronauci podróżując na Marsa i z powrotem przez 2 razy po 180 dni (tak zakłada agencja NASA), zainkasowaliby ok. $1320 \mathrm{mSv}$ promieniowania i jeszcze więcej podczas pobytu na Marsie. Tymczasem wg standardów NASA, astronauta w ciągu całej swojej kariery nie powinien otrzymać więcej niż 1000 $\mathrm{mSv}$. Otrzymanie takiej dawki w stosunkowo krótkim czasie znacznie zwiększa ryzyko śmiertelnej choroby nowotworowej.

Trzecią barierą kosmiczną jest zmienna temperatura, która w okolicach orbity Ziemi w rejonach nasłonecznionych przekracza $+100{ }^{\circ} \mathrm{C}$, natomiast $\mathrm{w}$ cieniu około $-180^{\circ} \mathrm{C}$ oraz w najbliższym otoczeniu Ziemi przestrzeń kosmiczna wypełniona jest przez wiatr słoneczny (protony i elektrony), który zaburza magnetyzm ziemski.

Czwarta bariera kosmiczna ma charakter techniczny i wiąże się $z$ brakiem urządzeń do generowania sztucznej grawitacji oraz odnawialnej energii paliwowej ${ }^{15}$, a zwłaszcza biologicznej (zamknięty układ obiegu wody i pożywienia).

14 Zabójcze dla życia dawki promieniowania, jakie otrzymaliby astronauci podczas lotu i pobytu na Marsie, są główną przeszkodą dla misji załogowej na tę planetę - potwierdzili naukowcy na podstawie danych zebranych przez marsjańskiego łazika Curiosity. Por. D. Manzey, Human missions to Mars: New psychological challenges and research issues, Acta Astronautica (2004)55, 781-790.

15 Np. HEL-3 jako paliwo do fuzji termojądrowej dopiero w perspektywie 20-30 lat jest 
Piąta bariera ma charakter biologiczny i wiąże się ze skutkami długotrwałej nieważkości, związanymi m.in. z zaburzeniem mechanizmu agregacji komórek (orientacji przestrzennej komórek), co sprawia, że zapłodnione komórki ginąc bez informacji grawitacyjnej, uruchamiają zaprogramowany mechanizm apoptozy, czyli śmierci komórkowej. Oznacza to, że wielopokoleniowe długotrwałe loty kosmiczne stoją pod znakiem zapytania $?^{16}$

Szósta bariera wiąże się pośrednio z kosmosem i dotyczy problemów psychologicznych związanych z efektami długotrwałej deprywacji sensorycznej i izolacji cywilizacyjnej, które prowadzą do degradacji psychiki, ponieważ niezaspokojony „głód sensoryczny"17 zmienia stany czynnościowe mózgu ${ }^{18}$. Opisany w literaturze przedmiotu „syndrom zimowników”" ${ }^{\text {, }}$ obejmujących takie objawy, jak: zaburzenie snu, depresja, spadek motywacji do pracy, zmienność nastrojów oraz niekontrolowana agresja, odnosi się także do „syndromu astronautów" w długoterminowych lotach kosmicznych ${ }^{20}$.

możliwe do pozyskania na Księżycu, jako stacji przesiadkowej na MARSA, gdyż Mars jest odległy od Ziemi od 55 do nawet 400 milionów kilometrów.

16 Dane z eksperymentów biologicznych Polskiej Akademii Nauk, prowadzonych na biosatelitach np. Kosmos 1129 dotyczących rozwój zarodków zwierząt w nieważkości.

17 J.F. Terelak, „Głód zmysłów” jako problem długotrwałych lotów kosmicznych, Astronautyka (1978)4, 20-22.

18 Potwierdzają to własne badania prowadzone podczas rocznego eksperymentu naturalnego w warunkach rocznej izolacji 20-osobowej załogi Stacji Antarktycznej PAN im. H. Arctowskiego. Por. J.F. Terelak, Człowiek w sytuacjach ekstremalnych: Izolacja antarktyczna, Warszawa 1982; J.F. Terelak, K. Kwarecki, S. Rakusa-Suszczewski, Deprywacja sensoryczna i izolacja społeczna jako problemy psychologii kosmicznej (Eksplikacje badań antarktycznych i eksperymentalnych), Postępy Astronautyki 33(1978)2, 7-31; J.F. Terelak, Introspekcje antarktyczne, Warszawa 1982.

19 J.F. Terelak, Aggresssion as a source of stimulation in experimental situations of sensory deprivation and social isolation, w: Psychology of Aggression. Selected Issues, red. J.F. Terelak, Z. Majchrzyk, Wyd. UKSW, Warszawa 2011, 51-72.

20 K. Binsted, R.L. Kobrick, M. O'Griofa, et al., Human factors research as part of a Mars exploration analogue mission on Devon Island, Planetary and Space Science (2010)58, 994-1006; S.L. Bishop, R. Kobrick, M. Battler, K. Binsted, FMARS 2007: Stress and coping in Antarctic Mars simulation, Acta Astronautica (2010)66, 1353-1367; J. Terelak, 
Siódma bariera fizjologiczna jest związana $\mathrm{z}$ objawami osteoporozy i zwiotczeniem mięśni po długotrwałej izolacji, co sprawia, że np. kosmonauci nie będą mogli o własnych siłach opuścić lądownik marsjański. Dotyczy to przede wszystkim astronautek, dla których kuracja testosteronem (hormonem męskim), powodująca przyrost masy mięśniowej, jest przeciwwskazaniem. Nie bez znaczenia jest problem zaburzeń ostrości widzenia pojawiający się zwłaszcza podczas długotrwałych latach kosmicznych u prawie $60 \%$ kosmonautów, którego mechanizm nie został jeszcze dostatecznie rozpoznany, poza przypuszczeniem, że jest związany z ciśnieniem płynu mózgowo-rdzeniowego i prac nerwu wzrokowego.

Ósma bariera logistyczna związana jest konstrukcją sztucznego środowiska zarówno statku kosmicznego, jak i bazy na obcej planecie (artificial satellite) $^{21}$, gwarantującego zamknięty system odnawialnej energii, atmosfery, wody, żywności oraz system utylizacji odpadów. Ten ostatni problem, związany z utrzymaniem sterylności na stacji kosmicznej, był przedmiotem testów prowadzonych na Stacji Kosmicznej MIR, za pomocą których zidentyfikowano 234 różnych bakterii i grzybów, które kosmonauci przetransportowali na sobie z Ziemi na pokład stacji kosmicznej, co mogło być przyczyną zgłaszanych przez kosmonautów dolegliwości, takich jak np.: zapalenie spojówek, choroby układu oddechowego czy kłopoty stomatologiczne.

Dziewiąta bariera ma charakter ekonomiczny, związany $z$ brakiem środków do budowy międzyplanetarnych statków kosmicznych oraz wyposażenia ekspedycji kosmicznych. Dotychczasowe systemy finansowania projektów kosmicznych, opartych na zdecentralizowanym sposobie pozyskiwania funduszy, są niewydajne.

Psychologiczny mechanizm zachowań agresywnych w sytuacji długotrwałej izolacji małej grupy zadaniowej, Medycyna Lotnicza 78 (1983)1, 28-30.

21 J.F. Terelak, Problemy symulowania „sztucznego środowiska” habitatu z perspektywy sozopsychologii kosmicznej, Studia Ecologiae et Bioethicae 2(2004)2, 575-594; A.A. Harrison, Humanizing outer space: Architecture, habitability, and behavioral health, Acta Astronautica (2010)66, 890-896. 
Dziesiąta bariera zwraca uwagę na trudności adaptacyjne do wielokrotnie, naprzemiennie zmieniających się warunków grawitacyjnych w lotach międzyplanetarnych, np. na Marsa: grawitacja ziemska - nieważkość - zmniejszona grawitacja księżycowa (stacja pośrednia) - nieważkość - grawitacja marsjańska - nieważkość grawitacja księżycowa - nieważkość - grawitacja ziemska ${ }^{22}$.

Ostatnią barierą ekologiczną są występujące zagrożenia ze strony „śmieci kosmicznych” i mikrometeorytów, które mogą uszkodzić statek kosmiczny oraz przebywających poza statkiem astronautów, wychodzących w otwartą przestrzeń kosmiczną. Przez teleskop widać z Ziemi około 50 tysięcy z pół miliona obiektów większych niż $1 \mathrm{~cm}$ znajdujących się na orbicie ziemskiej.

\section{REFLEKSJA ZAMIAST ZAKOŃCZENIA}

Najbliższa przyszłość astronautyki wiąże się z przygotowaniem lotu na Marsa ${ }^{23}$, najprawdopodobniej z „przystankiem” na Księżycu ${ }^{24}$. Od wielu lat naukowcy z wielu krajów w naziemnych laboratoriach marsjańskich, starają się opisać możliwości adaptacji człowieka do symulowanych warunków bytowania w długotrwałej izolacji socjalnej oraz testować zamknięte systemy odnawialnej energii, atmosfery, wody, żywności oraz system utylizacji odpadów ${ }^{25}$. Choć jest to niewątpliwie

22 P.A. Cowings, Psychophysiology of spaceflight and aviation, Polish Journal of Aviation Medicine and Psychology 19(2013)3, 9-16.

23 G. Horneck, R. Facius, M. Reichert, et al., HUMEX, a study on the survivability and adaptation of humans to long duration exploratory missions, part II: Missions to Mars, Advances in Space Research (2006)38, 752-759.

24 N. Goswami, P.G. Roma, P. DeBoever, et al., Using the Moon as a high-fi delity analogue environment to study biological and behavioral effects of long-duration space exploration, Planetary and Space Science (2012)74, 111-120.

25 N. Kanas, H. Harris, T. Neylan, et al., High versus low crew member autonomy during a 105day Mars simulation mission, Acta Astronautica (2011)69, 240-244; D. Manzey, Human missions to Mars: New psychological challenges and research issues, Acta Astronautica (2004)55, 781-790; P. Suedfeld, Historical space psychology: Early terrestrial explorations 
drugi „mały krok” ludzkości w drodze do bytowania w Kosmosie, to pytanie o sens astronautyki wciąż pozostaje otwarte. Refleksje takie po moim wykładzie monograficznym na temat możliwości bytowania w kosmosie, wygłoszonym na studiach doktoranckich na Wydziale Filozofii Chrześcijańskiej, zawarł w pracy zaliczeniowej ks. mgr Piotr Szydłowski: „Tam się nie da żyć, jeszcze długie lata upłyną zanim cokolwiek da się na tyle przystosować, żeby ktokolwiek z ludzi mógł tam przez jakiś czas zamieszkać. To nie ma sensu i choć nauka chce poznawać i pchać nasz rozwój do przodu i choć dzięki temu mamy lepsze sprzęty i lekarstwa ${ }^{26}$, to życie tam nie ma sensu. Może racje miał Stwórca, że to Ziemia i tylko Ziemia jest naszym domem?"27.

Spotkać można i odmienne refleksje, wynikające $\mathrm{z}$ wiary w możliwości adaptacyjne człowieka, który przez wiele tysięcy lat dostosował się do bardzo zróżnicowanych warunków ziemskich, nie tyle dzięki biernej adaptacji, jak to czynią inne organizmy ziemskie, ale głównie dzięki adaptacji inteligentnej, cechującej się innowacyjnym przekształcaniem środowiska ziemskiego. W tym można upatrywać

as Mars analogues, Planetary and Space Science (2010)58, 639-645; C. Tafforin, The Mars-500 crew in daily life activities: An ethological study, Acta Astronautica (2013)91, 69-76.

26 Wśród najważniejszych wynalazków, jakie zawdzięczamy lotom kosmicznym, są m.in.: (1) wkładki do butów, będących częścią wyposażenia skafandra kosmonauty; (2) filtry wodne do permanentnego oczyszczania wody w obiegu zamkniętym; (3) mleko modyfikowane, wykorzystywane na Ziemi do karmienia niemowlą; (4) pompa sercowa VAD (Ventricular Assist Device), zbudowana na wzór głównego silnika promu kosmicznego; (5) tomografia komputerowa MRI (Magnetic Resonance Imaging), opracowana na potrzeby programu kosmicznego Apollo do poprawy zdjęć przesyłanych z Księżyca; (6) ResQPOD urządzenie do resuscytacji kosmonautów powracających na Ziemię, wykorzystywane obecnie powszechnie w medycynie; (7) termometr na podczerwień skonstruowany przez NASA dla pomiaru promieniowania podczerwonego emitowanego przez gwiazdy i planety; (8) lekarstwa ograniczające osteoporozę, ułatwiające życie kobiet w okresie menopauzy, itp. http://www.esa.int/Our Activities/Space Engineering Technology; http://astropolis. pl/topic/48859-z-orbity-na-ziemie-kosmiczne-technologie-w-codziennym-zyciu/

27 P. Szydłowski, I co dalej...?, praca zaliczeniowa z wykładu monograficznego dla doktorantów na Wydziale Filozofii Chrześcijańskiej, pt. Psychologia grawitacyjna: nowe wyzwania cywilizacyjne, Warszawa 2016 (maszynopis). 
sens rozpoczętej w XX wieku eksploracji otwartego Kosmosu, czego symbolem jest wysłanie sond kosmicznych Voyager (1972) i Pioneer (1973), które przekroczyły kres naszego Układu Słonecznego i są odważnym krokiem w poszukiwaniu cywilizacji pozaziemskiej ${ }^{28}$.

\section{BIBLIOGRAFIA}

Ambler R.K., Berkshire J.R., O'Connor W.F., The identification of potential astronauts, Pensacola 1961, Report 33.

Binsted K., Kobrick R.L., O'Griofa M. et al., Human factors research as part of a Mars exploration analogue mission on Deron Island, Planetary and Space Science (2010)58, 994-1006.

Bishop S.L., Kobrick R., Battler M., Binsted, K., FMARS 2007: Stress and coping in Antarctic Mars simulation, Acta Astronautica (2010)66, 1353-1367.

Boyda J.E., Kanasa N., Gushin V.I., Saylor S., Cultural differences in patterns of mood states on board the International Space Station, Acta Astronautica (2007)61, 668-671.

Chaikin A. The loneliness the long-distance astronaut, Discover (1985)2, 20-31.

Christensen J.M., Talbot J.M., A review of the psychological aspects of space flight. Aviation, Space and Environmental Medicine 57(1986)3, 203-212.

Cowings P.A., Psychophysiology of spaceflight and aviation, Polish Journal of Aviation Medicine and Psychology 19(2013)3, 9-16.

DeLaTorre G.G., Baarsen B., Ferlazzo F. et al., Future perspectives on space psychology: Recommendations on psychosocial and neurobehavioural aspects of human space flight, Acta Astronautica (2012)81, 587-599.

Eberhard J.W., Smith K.T., The problem of off duty time in long duration space mission: An annotated bibliography, Serendipity Associates, McLean, Wirginia 1967.

Goswami N., Roma P.G., DeBoever P., et al., Using the Moon as a high-fidelity analogue environment to study biological and behavioral effects of long-duration space exploration, Planetary and Space Science (2012)74, 111-120.

28 Sondy te są swoistą wizytówką Ziemian, gdyż zawierają syntetyczne informacje o stanie cywilizacji ziemskiej z okresu XX wieku nowożytnej ery, obejmujące m.in. takie dane jak np. (1) obraz kobiety i mężczyzny (binarny zapis wzrostu człowieka); (2) informacje o podstawowym pierwiastku ziemskim - wodorze; (3) odległości od najbliższych pulsarów oraz kierunek i odległość od środka Galaktyki; (4) schemat układu słonecznego. Na każdej z sond zamieszczono plakietki z naniesionymi ścieżkami stanowiącymi przekaz audio-wizualny obrazów i dźwięków z planety Ziemia. Dodatkowo wykonano nagrania powitania w 56 językach (do płyty dołączono igłę i instrukcję jak odtworzyć zapis). 
Harrison A.A., Humanizing outer space: Architecture, habitability, and behavioral health, Acta Astronautica (2010)66, 890-896.

Hermaszewski M., Psychological aspects of space flights, Polish Journal of Aviation Medicine and Psychology 19(2013)3, 5-8.

Horneck G., Facius R., Reichert M. et al., HUMEX, a study on the survivability and adaptation of humans to long duration exploratory missions, part II: Missions to Mars, Advances in Space Research (2006)38, 752-759.

Kalery A.Y., Sorokin I.V., Tyurin M.V., Human space exploration beyond the international space station: Role of relations of human, machine and the "Earth", Acta Astronautica (2010)67, 925-933.

Kanas N., From Earth's orbit to the outer planets and beyond: Psychological issues in space, Acta Astronautica (2011)68, 576-581.

Kanas N., Harris H., Neylan T. et al., High versus low crew member autonomy during a 105-day Mars simulation mission, Acta Astronautica (2011)69, 240-244.

Kozerenko O.P., Radkowski G., Terelak J., Mikshik O., The problem of man's psychic adaptation under the space flight conditions, w: Current Trends in Cosmic Biology and Medicine, II, red. K. Boda and V.M. Baranov, Slovak Academy of Sciences, Ivanka Pri Dunaji (CSRF) 1991, 91-94.

Kwarecki K., Terelak J., Medycyna i psychologia kosmiczna, Wiedza Powszechna „Omega”, Warszawa 1980.

Manzey D., Human missions to Mars: Nerw psychological challenges and research issues, Acta Astronautica (2004)55, 781-790.

Medycyna lotnicza i kosmiczna, red. S. Barański, PZWL, Warszawa 1977.

Suedfeld P., Historical space psychology: Early terrestrial explorations as Mars analogues, Planetary and Space Science (2010)58, 639-645.

Suedfeld P., Brcic J., Legkaia K., Coping with the problems of space flight: Reports from astronauts and cosmonauts, Acta Astronautica (2009)65, 312-324.

Tafforin C., The Mars-500 crew in daily life activities: An ethological study, Acta Astronautica (2013)91, 69-76.

Terelak J.F., Aggresssion as a source of stimulation in experimental situations of sensory deprivation and social isolation, w: Psychology of Aggression. Selected Issues, red. J.F. Terelak, Z. Majchrzyk, Wyd. UKSW, Warszawa 2011, 51-72.

Terelak J.F., Current research and trends in Aviation Psychology in Poland, Aviation, Space and Environmental Medicine 62(1991)9, 903-908.

Terelak J.F., Cztowiek w sytuacjach ekstremalnych: Izolacja antarktyczna. Wyd. MON, Warszawa 1982.

Terelak J.F., „Gtód zmystów” jako problem dtugotrwatych lotów kosmicznych, Astronautyka (1978)4, 20-22. 
Terelak J.F., Introspekcje antarktyczne. Wyd. MON, Warszawa 1982.

Terelak J.F., Problemy symulowania , sztucznego środowiska" habitatu z perspektywy sozopsychologii kosmicznej, Studia Ecologiae et Bioethicae 2(2004)2, 575-594.

Terelak J.F., Psychologiczny mechanizm zachowań agresywnych w sytuacji dtugotrwatej izolacji matej grupy zadaniowej, Medycyna Lotnicza 78(1983)1, 28-30.

Terelak J.F., The emergence and development of space psychology in Poland: The significance of historical space fight of Mirostaw Hermaszewski, Polish Journal of Aviation Medicine and Psychology 19(2013)3, 23-36.

TerelakJ.F., Kwarecki K., Rakusa-Suszczewski S., Deprywacja sensoryczna i izolacja spoteczna jako problemy psychologii kosmicznej (Eksplikacje badań antarktycznych i eksperymentalnych), Postępy Astronautyki 33(1978)2, 7-31.

\title{
HUMANS IN SPACE: ADAPTATIONAL BARRIERS \\ FROM AN ASTRONAUTICAL PERSPECTIVE
}

\begin{abstract}
This article provides a review of current advances in astronautics with particular focus on medical and psychological barriers preventing long space travels. Our intellectual and emotional connection with the Universe has been recorded since the dawn of time, as evidenced by the advances in cosmology and astronomy on the one hand and in religious iconography and fantasy/science-fiction literature on the other. The collected pool of scientific data and current beliefs regarding the Universe provide the background for the development of tools designed to verify current hypotheses (e.g. telescopes, satellites, space probes). However, this happened only in the $20^{\text {th }}$ century when humans ventured to "touch" the Universe using senses other than vision. This step-by-step process was greatly advanced by the development of extraterrestrial transportation, including space ships (both orbital and interplanetary) and space stations. This activity, referred to in the literature as astronautics, became the source of new hopes for the exploration of space as well as of new myths regarding the future "conquest" thereof.
\end{abstract}

Keywords: space, astronautics, space medicine and psychology

\author{
JAN F. TERELAK \\ j.terelak@uksw.edu.pl \\ Uniwersytet Kardynała Stefana Wyszyńskiego w Warszawie, Instytut Psychologii \\ Wóycickiego 1/3, 01-938 Warszawa
}

DOI: 10.21697/spch.2016.52.3.11 